\title{
Litter Mixture Interactions at the Level of Plant Functional Types are Additive
}

\author{
Bart Hoorens, ${ }^{1,2}$ Martin Stroetenga, ${ }^{1}$ and Rien Aerts ${ }^{1 *}$ \\ ${ }^{1}$ Institute of Ecological Science, Department of Systems Ecology, VU University Amsterdam, De Boelelaan 1085, 1081 HV Amsterdam, \\ The Netherlands; ${ }^{2}$ Tauw bv, P.O. Box 3015, 3502 GA Utrecht, The Netherlands
}

\begin{abstract}
It is very difficult to estimate litter decomposition rates in natural ecosystems because litters of many species are mixed and idiosyncratic interactions occur among those litters. A way to tackle this problem is to investigate litter mixing effects not at the species level but at the level of Plant Functional Types (PFTs). We tested the hypothesis that at the PFT level positive and negative interactions balance each other, causing an overall additive effect (no significant interactions among PFTs). Thereto, we used litter of four PFTs from a temperate peatland in which random draws were taken from the litter species pool of each PFT for every combination of 2 , 3 , and 4 PFTs. Decomposition rates clearly differed among the 4 PFTs (Sphagnum spp. < graminoids $=\mathrm{N}$-fixing tree $<$ forbs) and showed little variation within the PFTs (notably for the Sphagnum mosses and the graminoids). Significant positive
\end{abstract}

\section{INTRODUCTION}

Litter decomposition provides the main source of nutrients for biological activity in almost all terrestrial ecosystems. During the process of litter decomposition, dead plant material is broken down into inorganic forms of carbon and nutrients and

Received 26 March 2009; accepted 20 October 2009; published online 18 November 2009

Author contributions: BH partly conceived research, performed research, analyzed data and wrote paper; MS performed part of the research; and RA designed study, wrote part of the paper.

*Corresponding author; e-mail: rien.aerts@falw.vu.nl interactions (4 out of 11) in the PFT mixtures were only found after 20 weeks and in all these combinations Sphagnum was involved. After 36 and 56 weeks of incubation interactions were not significantly different from zero. However, standard deviations were larger than the means, indicating that positive and negative interactions balanced each other. Thus, when litter mixture interactions are considered at the PFT level the interactions are additive. From this we conclude that for estimating litter decomposition rates at the ecosystem level, it is sufficient to use the weighted (by litter production) average decomposition rates of the contributing PFTs.

Key words: Additive effects; Decomposition; Litter production; Moisture effects; Peatland; Species identity effects; Sphagnum. stable organic matter (Parton and others 2007). The litter decomposition rate is closely linked with important ecosystem attributes such as productivity, plant species composition, and food-chain dynamics (Grime and others 1996; Aerts 1999; Cornwell and others 2008), and an in-depth understanding of the determinants of litter decomposition rate will greatly contribute to understanding the functioning of terrestrial ecosystems. Moreover, litter and soil organic matter constitute an important carbon store at a global scale and decomposition of this organic matter provides an important feedback to atmospheric 
$\mathrm{CO}_{2}$ concentrations (Gorham 1991; Sitch and others 2003; Krinner and others 2005).

Litter decomposition studies have very often dealt with the decomposition of single-species litter, but most terrestrial ecosystems contain multiple species of plants and so the litter layer is in most cases comprised of leaves from a number of species. As a consequence of litter mixing, the decomposition of a given litter type may be influenced by the presence of other litter types. Mixing litter can either accelerate or decelerate decomposition and differences between observed and expected mass loss of $20-30 \%$ are not uncommon (Montagnini and others 1993; Wardle and others 1997; Anderson and Hetherington 1999; Hoorens and others 2003; Gartner and Cardon 2004; Hättenschwiler and others 2005; Ball and others 2008). Interaction effects may be caused by chemical interactions between the component litters or by changes in the micro-environment in which the litter is decomposed (Hector and others 2000; Hoorens and others 2003; Madritch and Cardinale 2007; Schimel and Hättenschwiler 2007). Several studies found that litter mixtures decompose faster than expected when the component species differ in their litter nutrient concentration (Wardle and others 1997; Quested and others 2003). In this case, the relatively high amounts of nutrients in one of the litter types could stimulate the decomposition of the other litter in the mixture. It is hypothesized that these nutrients are transported from one litter type to another by diffusion through a water film and/or actively transported through the hyphae of fungi connecting the different litter types (McTiernan and others 1997). Negative interactions occur (for example, Wardle and others 1997; Robinson and others 1999; Hoorens and others 2003) when for instance one of the component litter types contains high amounts of secondary compounds, such as phenolics. Phenolics may slow down the decomposition of litter mixtures in several ways. Polyphenolics, such as tannins, form resistant complexes with proteins (Hättenschwiler and Vitousek 2000). Tannins not only complex with digestive fungal extracellular enzymes, but probably also affect the structural and/or enzymic proteins within the hyphae, thus directly inhibiting microbial growth and activity (Schimel and others 1998). Polyphenols also complex with proteins, which may occlude the $\mathrm{N}$ into complexes that are unavailable to decomposer organisms and consequently slow down decomposition (Hättenschwiler and Vitousek 2000). This implies that if one species in a mixture contains large amounts of phenolics, this could slow down the decomposition of the entire litter mixture.
Currently, there is consensus about the fact that these interactions are not driven by litter species richness by itself, but by the composition of the litter mixture, that is, the specific effect that a species has on its 'neighbor', that is, by species identity (Hättenschwiler and others 2005; Ball and others 2008). In general, these interactions mainly occur in the initial stages of litter decomposition, when chemical interactions are most likely to occur (Hättenschwiler and others 2005).

As a result of the importance of litter identity for litter mixing effects, it is very hard to predict for natural ecosystems, where litter of many species is mixed, what the litter decomposition rate for the entire ecosystem will be. This poses real problems for ecosystem modelers as it is impossible to predict at large spatial scales, where information about species identities is missing, the overall decomposition rate (compare Sitch and others 2003; Krinner and others 2005). This has important implications for the accuracy of the carbon balance modules in Dynamic Global Vegetation Models (DGVMs). A way to overcome this problem is to consider decomposition rates at the level of Plant Functional Types (PFTs). The concept of PFTs has been commonly applied to model the effects of plant traits on ecosystem processes, because of the need to reduce the complexity and diversity of real ecosystems. This is usually achieved by grouping species into more convenient (that is, smaller) number of units. This grouping is based upon the notion that many ecologists believe that the essential information on the plant-mediated controls on the functioning of ecosystems can be captured by grouping plant species into PFTs (for example, Chapin and others 1996). Some species respond in a more similar way than others, that is, are functionally similar with respect to the variable studied, and hence can be grouped together for the purpose of modelling. Once plants have been grouped together into PFTs according to the plant trait that is studied, information at the ecosystem level can be derived from the relative contribution of each PFT to total ecosystem plant biomass.

The concept of PFTs has also been used to study plant litter decomposition. Several studies found that differences in litter decomposability corresponded well with an a priori distinction of PFTs based on traits of live plants, but the overlap among PFTs was considerable (for example Cornelissen 1996; Peréz-Harguindeguy and others 2000; Quested and others 2003). However, for accurately modelling plant litter decomposition at the ecosystem level such an approach is not sufficient as interactions at the level of PFTs may also occur. As 
far as we know, information on interactions during plant litter decomposition at the level of PFTs is lacking as these interactions have until now only been studied at the species level. From these studies it appears that these interactions are highly idiosyncratic due to the specific properties of the species in the mixtures (for example, Wardle and others 2003; Hättenschwiler and others 2005; Ball and others 2008). However, these idiosyncratic interactions may be positive, negative, or neutral. We hypothesize that at the PFT level positive and negative interactions balance each other, causing an overall additive effect (no significant interaction). Thus, at the PFT level the decomposition of PFT mixtures would equal the sum of the average decomposition rates of the contributing PFTs. If true, it would be sufficient to characterize the decomposability of each PFT and estimate ecosystem decomposition rate by summing the average decomposition rate of each PFT, weighted by its relative contribution to total litter production. We tested our hypothesis with litter of four PFTs (Sphagnum mosses, graminoids, forbs, and a N-fixing tree) from a temperate peatland in the Netherlands.

\section{Materials ANd Methods}

\section{Litter Collection}

For this experiment we used litter batches that had also been collected for a parallel experiment in which we investigated whether the strength of litter interactions was determined by differences in litter chemistry (Hoorens and others 2003). The species and their chemical characteristics are listed in Table 1. The litter collection procedures are fully described in Hoorens and others (2003). In short, freshly senesced leaf litter was collected from peatlands in The Netherlands during the period of plant senescence (September to mid December). Litter was collected from 15 species belonging to four PFTs. We defined the PFTs before the start of the experiment. Our definition of these PFTs was based upon a mix of both taxonomy and functional attributes of living plants, similar to the grouping into 'plant growth forms' by Chapin and others (1996) for cool and cold biomes. Litter was collected from a wide array of species that included the most common representatives of the PFTs present. The species were classified into the following PFTs: peat mosses, hereafter referred to as Sphagnum mosses; graminoids (grasses and sedges); forbs; and a nitrogen-fixer, the deciduous tree Alnus glutinosa (Table 1). We included a $\mathrm{N}$-fixing species as the litter of these species usually is very rich in nitrogen (Cornelissen 1996) and may as such contribute significantly to chemical interactions in the decomposing litter (see "Introduction"). Unfortunately, there was only one representative of $\mathrm{N}$-fixing species present in the peatlands that we investigated that produced sufficient amounts of litter for our experiment. However, given the potential importance of this PFT, we decided to include it. The litter of all species was collected from peatlands at the 'Westbroekse Zodden' and 'Gagelpolder', both situated in the central part of The Netherlands.

Because of considerable differences between the species, it was necessary to collect litter over a long period of time. We used different methods depending on species and functional group. We collected the upper $3-5 \mathrm{~cm}$, including the capitula from the Sphagnum mosses. We did realize that this material was not true Sphagnum litter, but we used this material because it is notoriously difficult to define what really constitutes fresh Sphagnum litter (Johnson and Damman 1993). Furthermore, under natural field conditions, freshly senesced litter from other species will decompose while in contact with (living) Sphagnum capitula. To collect freshly senesced litter from the graminoid species, we clipped the senesced part of a leaf that was still partly green (Craine and others 1999). Depending on species, forb litter was either collected from the soil surface or removed from the plant itself.

All litter (except Sphagnum) was air dried at room temperature immediately after collection and stored until further use. The Sphagnum material was freeze-dried, to kill the tissues. Subsamples from the litter of each species were retained for the determination of air versus oven dry mass ratio.

\section{Experimental Setup}

Polyethylene litterbags $(9 \times 10 \mathrm{~cm}, 0.5 \mathrm{~mm}$ mesh $)$ were filled with $1 \mathrm{~g}( \pm 0.05 \mathrm{~g}$, weighed to the nearest $\mathrm{mg}$ ) air-dried litter, consisting of either litter from a single plant species, or a mixture in equal proportions of litter from species belonging to 2, 3, or 4 different PFTs. In that case, equal amounts of litter was taken from a randomly chosen species of each of the contributing PFTs. Three litterbags (for three different retrieval dates) were prepared for each species combination.

Because we studied interactions during litter decomposition from a PFT perspective, the litter mixtures were replicated at the PFT level. The replicates for each PFT mixture thus consisted of combinations of species that had been randomly 
Table 1. List of Species (Classified into Plant Functional Types) Used in the Experiment and Litter C, N, P, and Total Phenolics Concentrations

\begin{tabular}{|c|c|c|c|c|}
\hline & $\mathrm{C}\left(\mathrm{mg} \mathrm{g}^{-1}\right)$ & $\mathrm{N}\left(\mathrm{mg} \mathrm{g}^{-1}\right)$ & $\mathrm{P}\left(\mathrm{mg} \mathrm{g}^{-1}\right)$ & Phenolics ( $\mathrm{mg} \mathrm{g}^{-1}$ ) \\
\hline \multicolumn{5}{|l|}{ Sphagnum mosses } \\
\hline S. contortum & 444.7 & 11.0 & 0.44 & 4.1 \\
\hline S. fimbriatum & 452.9 & 15.6 & 0.82 & 6.0 \\
\hline S. palustre & 458.2 & 16.7 & 0.93 & 4.7 \\
\hline S. squarrosum & 457.2 & 11.5 & 0.76 & 5.4 \\
\hline S. recurvum & 458.1 & 6.6 & 0.50 & 5.7 \\
\hline \multicolumn{5}{|l|}{ Graminoids } \\
\hline Eriophorum angustifolium & 477.6 & 8.8 & 0.39 & 33.1 \\
\hline Molinia caerulea & 480.0 & 6.6 & 0.16 & 9.9 \\
\hline Carex rostrata & 460.2 & 5.7 & 0.31 & 16.6 \\
\hline Carex nigra & 481.0 & 7.4 & 0.28 & 31.4 \\
\hline \multicolumn{5}{|l|}{ Forbs } \\
\hline Lysimachia thyrsiflora & 468.2 & 8.8 & 0.51 & 18.1 \\
\hline Potentilla palustris & 481.8 & 14.5 & 0.70 & 43.0 \\
\hline Succisa pratensis & 463.2 & 6.2 & 0.46 & 50.0 \\
\hline Potentilla erecta & 464.8 & 9.0 & 0.62 & 43.8 \\
\hline Cirsium dissectum & 412.3 & 11.1 & 0.68 & 35.2 \\
\hline \multicolumn{5}{|l|}{ N-fixating species } \\
\hline Alnus glutinosa & 517.0 & 25.2 & 0.72 & 37.8 \\
\hline
\end{tabular}

chosen from the species pool of the appropriate PFTs. However, identical species combinations were discarded (this occurred only twice). For each PFT combination there were 7 replicates, so 7 random draws.

The litterbags were incubated under field conditions at 'Het Guisveld', a peatland ecosystem near Westzaan, $\pm 20 \mathrm{~km}$ northwest of Amsterdam, The Netherlands $\left(52^{\circ} 29^{\prime} \mathrm{N}, 4^{\circ} 46^{\prime} \mathrm{E}\right)$. The vegetation at this site used to be dominated by Sphagnum peat moss, but in recent years the moss Polytrichum commune (L.) has almost entirely displaced Sphagnum as the dominant species. This particular site was chosen because of the similar abiotic conditions to the sites where the litter was collected, except for the explicit absence of Sphagnum. We refrained from using Sphagnum as the incubation environment to avoid confounding with those litter mixtures that contained Sphagnum peat moss. So, by choosing this peatland we prevented that the Sphagnum species would have a 'home advantage' due to interactions with a similar soil substrate. The litterbags were incubated in seven replicate blocks, each block consisting of three plots for the three different retrieval dates. In February the litterbags were inserted vertically into the moss layer to such a depth that the top of the litterbag was at surface level. Litterbags were retrieved after 20, 36, and 56 weeks. After retrieval, the remaining litter was cleaned, dried $\left(48 \mathrm{~h}, 80^{\circ} \mathrm{C}\right)$, and weighed.

\section{Calculations and Statistical Analyses}

To test whether the decomposability of the species (within PFTs) corresponded with the a priori, subjective PFT classification of species based on liveplant traits, the average percentages initial weight remaining of the PFTs were compared using analysis of variance. For this analysis, we used the decomposition data of Hoorens and others (2003). Next, interactions in litter mixtures were determined by first calculating the expected mass remaining, based on the remaining mass in the single-species litterbags of the component species that were incubated in the same plot. This was calculated as follows (compare Briones and Ineson 1996; McTiernan and others 1997):

$$
\begin{aligned}
& \text { Expected mass remaining } \\
& \begin{array}{l}
=\left(M_{1} /\left(M_{1}+\ldots+M_{n}\right)\right) * R_{1}+\ldots+ \\
\quad\left(M_{n} /\left(M_{1}+\ldots+M_{n}\right)\right) * R_{n}
\end{array}
\end{aligned}
$$

where $R$ refers to the remaining mass of a species in the single-species litterbag and $M$ refers to the estimated initial litter dry mass of a species in the mixture. The suffixes indicate which particular species is referred to: from species 1 to species $n$ (the maximum number of species in that particular mixture).

Interaction strength was calculated as: $1-$ (observed/expected mass remaining). When 
observed mass remaining was lower than expected the interaction was positive and when it was higher the interaction was negative.

We tested for each PFT mixture if the interactions differed significantly from zero using $t$-tests. As a result, we performed many separate $t$-tests. For every one of those tests (assuming a 5\% significance level), one accepts a $5 \%$ chance of a type I error. Thus, it is to be expected that some (approximately one out every 20 tests) of these individual tests will show significant differences by chance alone. To test whether the observed number of significant $t$-tests was different from what would be expected by chance, we used G-tests or log-likelihood tests (see for example, Sokal and Rohlff 1995). In the present set-up this would lead to two significant $t$-tests by chance alone.

\section{RESUltS}

The coefficients of variation in percentage mass remaining within the PFTs were quite different among the PFTs, but were generally low (Table 2; Figure 1). Especially, the variation between the different Sphagnum mosses was particularly low, which indicates that the Sphagnum species that we studied formed a very homogeneous group in terms of litter decomposability. The variation within the graminoids was higher, but still relatively low, whereas the variation within the forbs was very high. As a result, the average litter decomposability of Sphagnum mosses, the graminoids and the forbs were all significantly different from each other $(P<0.05)$ (Figure 1). This figure, furthermore, shows that there was a significant increase in litter decomposability from Sphagnum mosses, the graminoids to the forbs. Thus, the distinction that we made between the PFTs was clearly reflected in the differences among the decomposability of these PFTs. As Alnus was a PFT containing only a single species (A. glutinosa), it does not make sense to consider that value as

Table 2. Average Percentage Remaining Mass (After 56 weeks) of the Different Plant Functional Types with Their Respective Coefficients of Variation

\begin{tabular}{lll}
\hline PFT & $\begin{array}{l}\text { Average } \\
\text { percentage } \\
\text { mass remaining }\end{array}$ & $\begin{array}{l}\text { Coefficient of } \\
\text { variation (\%) }\end{array}$ \\
\hline Sphagnum mosses & 78.2 & 3.3 \\
Graminoids & 53.6 & 10.0 \\
Forbs & 23.9 & 61.8 \\
Alnus glutinosa & 45.6 & n.a. \\
\hline
\end{tabular}

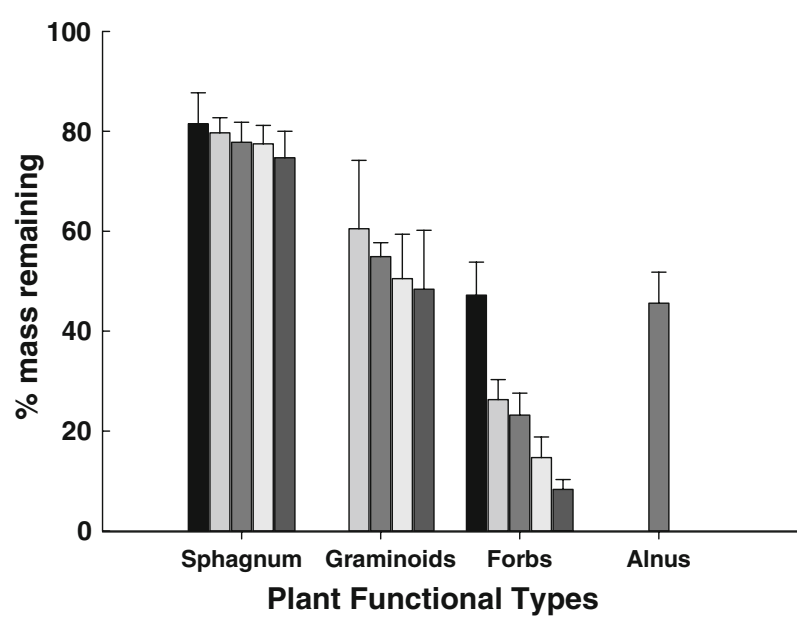

Figure 1. Mean $( \pm S D, n=7)$ percentage remaining litter mass in the monocultures of the 15 analyzed species (rank order of species is the same as in Table 1) after 56 weeks, grouped according to the Plant Functional Types.

representative for the $\mathrm{N}$-fixing trees and to compare it to the other PFTs. The decomposition rate of Alnus glutinosa was not different from that of the graminoids and slower than that of the forbs.

For these peatland PFTs the interaction strengths were in general relatively low (close to zero) and did not change systematically with time (Table 3 ). Only four significant interactions occurred in the first litterbag retrieval (after 20 weeks), whereas none were present after 36 and 56 weeks. However, these four interactions were significantly more than the two that would be expected to occur by chance (G-test). Interestingly, all four of these mixtures contained Sphagnum, and all interactions were positive, that is, the presence of Sphagnum accelerated the decomposition of the other PFT in the mixtures.

\section{Discussion}

\section{Litter Mixture Interactions at the PFT Level}

To our knowledge, this is the first study that has approached litter mixture interactions from the PFT perspective. This is surprising, given the fact that in natural ecosystems litter mixtures (almost) always consist of representatives of various PFTs and that the mixture effects at the species level are highly idiosyncratic.

The patterns in leaf litter decomposition rates among the various PFTs are in agreement with those found in an earlier compilation of leaf litter decomposition rates in temperate fens and bogs (Aerts and others 1999). This pattern also holds 
Table 3. Mean Interaction Strength Values $( \pm \mathrm{SD}, n=7)$ in the Peatland Litter Mixtures After 20, 36, and 56 Weeks

\begin{tabular}{|c|c|c|c|c|c|c|}
\hline \multirow[t]{2}{*}{ PFT mixture } & \multicolumn{2}{|c|}{20 weeks } & \multicolumn{2}{|c|}{36 weeks } & \multicolumn{2}{|c|}{56 weeks } \\
\hline & Mean & SD & Mean & SD & Mean & SD \\
\hline $1+2$ & 0.05 & 0.07 & 0.03 & 0.04 & 0.04 & 0.13 \\
\hline $1+3$ & 0.05 & 0.05 & -0.02 & 0.08 & 0.01 & 0.08 \\
\hline $1+4$ & -0.01 & 0.06 & 0.01 & 0.08 & -0.03 & 0.08 \\
\hline $2+3$ & 0.00 & 0.10 & -0.06 & 0.08 & -0.12 & 0.22 \\
\hline $2+4$ & 0.04 & 0.06 & -0.03 & 0.12 & -0.04 & 0.18 \\
\hline $3+4$ & 0.01 & 0.10 & 0.06 & 0.18 & 0.03 & 0.29 \\
\hline $1+2+3$ & 0.07 & 0.07 & 0.00 & 0.06 & 0.02 & 0.11 \\
\hline $1+2+4$ & 0.04 & 0.04 & 0.05 & 0.09 & -0.11 & 0.13 \\
\hline $2+3+4$ & 0.00 & 0.08 & 0.02 & 0.15 & 0.03 & 0.16 \\
\hline $1+3+4$ & 0.08 & 0.06 & 0.02 & 0.06 & -0.05 & 0.07 \\
\hline $1+2+3+4$ & 0.04 & 0.09 & -0.01 & 0.10 & 0.04 & 0.08 \\
\hline
\end{tabular}

Interactions in bold are significantly different from zero $(P<0.05)$. Mixtures contained randomly chosen species (see Table 1$)$ from the following Plant Functional Types 1 = Sphagnum mosses; 2 = Graminoids; 3 = Forbs; 4 = Alnus glutinosa.

when comparing them for peatland PFTs from various climatic zones, as Dorrepaal and others (2005) did not find any climatic influence when comparing the leaf litter decomposition rates of these PFTs for sub-arctic, cool temperate, and warm temperate sites. However, in our study site there were no evergreen species, except for a few individuals of Erica tetralix L., so this PFT was not included. It should be noted that in other peatlands this PFT can be more abundant.

In agreement with our hypothesis, in almost all replicate mixtures of species from the various PFTs the negative values of the interactions balanced the positive ones in other replicate mixtures, leading to hardly any significant net mean effects at the PFT level. The four significant interactions at the PFT level that occurred were only short-lived (20 weeks) and all contained Sphagnum (for a further discussion of that see "Positive PFT Interactions in the Presence of Sphagnum" section). In general, the mean interaction strength did not deviate much from zero and in most cases the standard deviations were larger than the means. The most likely explanation for this pattern is that litter mixture interactions are driven by the composition of the litter mixture, that is, the specific effect that a species has on its 'neighbor', that is, by species identity (Hättenschwiler and others 2005; Ball and others 2008). As a result, these interactions are highly idiosyncratic. Thus, when random draws are taken from PFTs as was done in the present study and the PFTs are then mixed, the resulting interactions are most likely also random draws from positive, neutral, and negative effects and this will lead to an average 'no effect', but with a relatively large standard deviation.
This absence of significant interactions at the PFT level has important implications for our estimates of overall decomposition rates in ecosystems, where the litters of very many species are mixed. In a way, the composition of those mixtures can be considered as the result of random draws from various PFTs. Our data strongly suggest that it is sufficient for an estimate of ecosystem litter decomposition rate to add the average decomposition rates of the contributing PFTs and weight them by their contribution to total litter production. Thus, interactions do not need to be included in the estimate. This would be an important simplification for estimates of ecosystem decomposition rates that are used in carbon balance modules in DGVMs (Sitch and others 2003; Krinner and others 2005). However, the accuracy of the overall decomposition rate is also determined by correct classification of the PFTs and by the coefficient of variation of litter decomposability in each PFT. In this peatland ecosystem the PFTs were all (except Alnus) significantly different from each other in terms of litter decomposability. This implies that the grouping based on litter decomposability corresponded well with our initial classification on the basis of liveplant traits (that is, plant life-forms). Additionally, two of the PFTs, namely Sphagnum and the graminoids, had little internal variation in terms of litter decomposability, which at least partly contributed to the average litter decomposability being significantly different among PFTs. Our results thus suggest that the a priori PFT classification (based on plant growth forms) for litter decomposability gave a clear-cut distinction among the four distinguished PFTs in the peatland ecosystem and that the mean 
values were good indicators of PFT decomposability.

It should be noted, however, that there is not always a clear-cut distinction in decomposability among PFTs. Although several studies found that differences in litter decomposability corresponded well with an a priori distinction of PFTs based on traits of live plants, the overlap among PFTs was considerable and the decomposability of adjacent PFTs was not significantly different (for example Cornelissen 1996; Peréz-Harguindeguy and others 2000; Quested and others 2003; Dorrepaal and others 2005). However, the low decomposability of peat mosses compared to vascular PFTs is a general phenomenon (Aerts and others 1999; Dorrepaal and others 2005). Nevertheless, the low variability that we found for the Sphagnum mosses is not necessarily a general phenomenon. Our study site is a fen, without the occurrence of the Sphagnum mosses that are characteristic for bogs with hummocks and hollows. These species are known to vary much more in decomposition rates (compare Johnson and Damman 1993; Aerts and others 1999; Turetsky and others 2008). Inclusion of these species would have led to much more variability in decomposition rates, but still the decomposition of the Sphagnum mosses would have been lower than that of the other PFTs (compare Aerts and others 1999).

\section{Positive PFT Interactions in the Presence of Sphagnum}

The significant interactions that occurred in the first litterbag retrieval (after 20 weeks) occurred in PFT mixtures containing Sphagnum, and were positive. This is surprising, not only because Sphagnum decomposed slowest in single-species litterbags, but also because Sphagnum has traditionally been thought to have a negative effect on decomposition of co-occurring species (for example, van Breemen 1995; Verhoeven and Toth 1995).

Actually, we have found positive interactions in litter mixtures containing Sphagnum before (Hoorens and others 2002). Several explanations have been offered to explain such positive interactions. First, it has been suggested that the water-retaining properties (the so-called 'sponge effect') of Sphagnum material maintain a more constant favorable micro-climate (that is, moist) for litter decomposition (Hoorens and others 2002; Wardle and others 2003). In other words, the presence of Sphagnum material may prevent the temporary desiccation of litter that might otherwise occur between rainfall events. Such effects on the micro-environment, notably on moisture availability have been proposed for other ecosystems as well (Hector and others 2000; Hoorens and others 2003; Schimel and Hättenschwiler 2007). However, this does not necessarily hold for all Sphagnum mosses. It is most manifest for Sphagnum mosses that are most abundant in hummocks. These species maintain a high water holding capacity through various structural and morphological characteristics, such as dense capitula, spreading and hanging branches, and hyaline cells that store water (Rydin and McDonald 1985). The Sphagnum mosses of the present study all possess these properties.

Second, it has been proposed that, due to the absence of true lignin, Sphagnum cell walls are relatively weak and easily start leaking decomposable cell contents in the early phases of the decomposition process (Verhoeven and others 1990). These easily decomposable cell contents might help the decomposition of other litter in a mixture. As this leaching of cell contents mainly occurs in the earlier phases of decomposition (Cadisch and Giller 1997), this might also explain the short-lived nature of the positive interaction in Sphagnum-containing litter mixtures.

Another explanation for the short-lived positive effects of Sphagnum might be found in the incubation environment. The litterbags were incubated in the field in a moss layer dominated by Polytrichum commune. This moss species can grow more than $10 \mathrm{~cm}$ per year. This implies that the litterbags were soon no longer at or near the surface, but deeper down the 'soil' profile. This would make them less susceptible to the effects of variations in moisture availability as deeper in the soil profile the microclimate is more constant, thus making the sponge effect no longer relevant.

\section{Implications for Ecosystem Processes}

Litter decomposition is a crucial process for the carbon balance of peatlands as their carbon accumulation rate is more determined by low decomposition rates of plant litter and soil organic matter (SOM) than by high primary production (Robinson 2002; Turetsky and others 2008; Vitt and others 2009). The low decomposability of Sphagnum mosses is of paramount importance (Aerts and others 1999; Turetsky 2003; Vasander and Kettunen 2006). Our study confirms that Sphagnum litter has the lowest decomposability and further we show that for this peatland there were hardly any significant litter mixture interactions and in the few cases observed, all involved Sphagnum 
mosses. This implies that at the PFT level, litter mixture interactions are additive.

This has important implications for the carbon balance modules in DGVMs as for estimating litter decomposition rates at the ecosystem level, it is sufficient to add the average decomposition rates of the contributing PFTs, weighted by their contribution to total litter production. These average decomposition rates of various PFTs are becoming more readily available as many studies provide data on this (for example, Cornelissen 1996; Aerts and others 1999; Quested and others 2003; Dorrepaal and others 2005; Cornwell and others 2008).

It should be realized that in the present study we included leaf litter only. Thus, we did not consider other important plant parts such as woody stems, roots, and rhizomes. To make a proper assessment of decomposition processes in peatlands, these organs should be studied as well as they may provide a major contribution to the peat accumulation process (compare Scheffer and Aerts 2000; Turetsky 2003; Vitt and others 2009). However, the main topic of the present study was to see if litter mixture interactions occur at the level of PFTs and for leaf litter this was not the case. Nevertheless, one of the next steps is to study whether interactions occur when other litter types than leaves are mixed. In addition to that, further tests are needed for longer incubation periods, other ecosystems and other climatic zones to show the robustness of the assumption that litter mixture interactions at the PFT level are additive.

\section{ACKNOWLEDGEMENTS}

We thank 'Staatsbosbeheer' for allowing us to work at the Guisveld and 'Vereniging Natuurmonumenten' to collect plant litter at their properties.

\section{OPEN ACCESS}

This article is distributed under the terms of the Creative Commons Attribution Noncommercial License which permits any noncommercial use, distribution, and reproduction in any medium, provided the original author(s) and source are credited.

\section{REFERENCES}

Aerts R. 1999. Interspecific competition in natural plant communities: mechanisms, trade-offs, and plant-soil feedbacks. J Exp Bot 50:29-37.

Aerts R, Verhoeven JTA, Whigham DF. 1999. Plant-mediated controls on nutrient cycling in temperate fens and bogs. Ecology 80:2170-81.
Anderson JM, Hetherington SL. 1999. Temperature, nitrogen availability and mixture effects on the decomposition of heather (Calluna vulgaris (L.) Hull) and bracken (Pteridium aquilinum (L.) Kuhn) litters. Funct Ecol 13:116-24.

Ball BA, Hunter MD, Kominoski JS, Swan CM, Bradford MA. 2008. Consequences of non-random species loss for decomposition dynamics: experimental evidence for additive and non-additive effects. J Ecol 96:303-13.

Briones MJI, Ineson P. 1996. Decomposition of Eucalyptus leaves in litter mixtures. Soil Biol Biochem 28:1381-8.

Cadisch G, Giller KE, Eds. 1997. Driven by nature. Plant litter quality and decomposition. Wallingford: $\mathrm{CAB}$ International.

Chapin FS, Bret-Harte MS, Hobbie SE, Zhong H. 1996. Plant functional types as predictors of transient responses of arctic vegetation to global change. J Veg Sci 7:347-58.

Cornelissen JHC. 1996. An experimental comparison of leaf decomposition rates in a wide range of temperate plant species and types. J Ecol 84:573-82.

Cornwell WK, Cornelissen JHC, Amatangelo K, Dorrepaal E, Eviner VT, Godoy O, Hobbie SE, Hoorens B, Kurokaw H, Perez Harguindeguy H, Quested HM, Santiago LS, Wardle DA, Wright IJ, Aerts R, Allison S, van Bodegom PM, Brovkin V, Chatain A, Callaghan TV, Diaz S, Garnier E, Gurvich DE, Kazakou E, Klein J, Read J, Reich PB, Soudzilovskaia NA, Vaieretti MV, Westoby M. 2008. Plant species traits are the predominant control on litter decomposition rates within biomes worldwide. Ecol Lett 11:1065-71.

Craine JM, Berin DM, Reich PB, Tilman D, Knops JMH. 1999. Measurement of leaf longevity of 14 species of grasses and forbs using a novel approach. New Phytol 142:475-81.

Dorrepaal E, Cornelissen JHC, Aerts R, Wallen B, van Logtestijn RSP. 2005. Are growth forms consistent predictors of leaf litter quality and decomposability across peatlands along a latitudinal gradient? J Ecol 93:817-28.

Gartner TB, Cardon ZG. 2004. Decomposition dynamics in mixed-species leaf litter. Oikos 104:230-46.

Gorham E. 1991. Northern peatlands: role in the carbon cycle and probable responses to climatic warming. Ecol Appl 1:182-95.

Grime JP, Cornelissen JHC, Thompson K, Hodgson JG. 1996. Evidence of a causal connection between anti-herbivore defence and the decomposition rate of leaves. Oikos 77:489-94.

Hättenschwiler S, Vitousek PM. 2000. The role of polyphenols in terrestrial ecosystem nutrient cycling. Trends Ecol Evol $15: 238-43$

Hättenschwiler S, Tiunov AV, Scheu S. 2005. Biodiversity and litter decomposition in terrestrial ecosystems. Annu Rev Ecol Evol Syst 36:191-218.

Hector A, Beale AJ, Minns A, Otway SJ, Lawton JH. 2000. Consequences of the reduction of plant diversity for litter decomposition: effects through litter quality and microenvironment. Oikos 90:357-71.

Hoorens B, Aerts R, Stroetenga M. 2002. Litter quality and interactive effects in litter mixtures: more negative interactions under elevated $\mathrm{CO}_{2}$ ? J Ecol 90:1009-16.

Hoorens B, Aerts R, Stroetenga M. 2003. Does initial litter chemistry explain litter mixture effects on decomposition? Oecologia 137:578-86.

Johnson LC, Damman AWH. 1993. Decay and its regulation in Sphagnum peatlands. Adv Bryol 5:249-96.

Krinner $G$ et al. 2005. A dynamic global vegetation model for studies of the coupled atmosphere-biosphere system. Global Biogeochem Cycles 19:GB1015. 
Madritch MD, Cardinale BJ. 2007. Impacts of tree species diversity on litter decomposition in northern temperate forests of Wisconsin, USA: a multi-site experiment along a latitudinal gradient. Plant Soil 292:147-59.

McTiernan KB, Ineson P, Coward PA. 1997. Respiration and nutrient release from tree leaf litter mixtures. Oikos 78:527-38.

Montagnini F, Ramstad K, Sancho F. 1993. Litterfall, litter decomposition and the use of mulch of four indigenous tree species in the Atlantic lowlands of Costa Rica. Agrofor Syst 23:39-61.

Parton WP, Silver WL, Burke IC, Grassens L, Harmon ME, Currie WS, King JY, Adair EC, Brandt LA, Hart SC, Fasth B. 2007. Global-scale similarities in nitrogen release patterns during long-term decomposition. Science 315:361-4.

Peréz-Harguindeguy N, Díaz S, Cornelissen JHC, Vendramini F, Cabido M, Castellanos A. 2000. Chemistry and toughness predict leaf litter decomposition rates over a wide spectrum of functional types and taxa in central Argentina. Plant Soil 218:21-30.

Quested HM, Cornelissen JHC, Press MC, Callaghan TV, Aerts R, Trosien F, Riemann P, Gwynn-Jones D, Kondratchuk A, Jonasson SE. 2003. Decomposition of sub-arctic plants with nitrogen economies: a functional role for hemiparasites. Ecology 84:3209-21.

Robinson CH. 2002. Controls on decomposition and soil nitrogen availability at high latitudes. Plant Soil 242:65-81.

Robinson CH, Kirkham JB, Littlewood R. 1999. Decomposition of root mixtures from high arctic plants: a microcosm study. Soil Biol Biochem 31:1101-8.

Rydin H, McDonald AJS. 1985. Tolerance of Sphagnum to water level. J Bryol 13:571-8.

Scheffer RA, Aerts R. 2000. Root decomposition and soil nutrient and carbon cycling in two temperate fen ecosystems. Oikos 91:541-9.

Schimel J, Hättenschwiler S. 2007. Nitrogen transfer between decomposing leaves of different $\mathrm{N}$ status. Soil Biol Biochem 39:1428-36.

Schimel JP, Cates RG, Ruess R. 1998. The role of balsam poplar secondary chemicals in controlling soil nutrient dynamics through succession in the Alaskan taiga. Biogeochemistry 42:221-34.

Sitch S, Smith B, Prenctice IC, Arneth A, Bondeau A, Cramer W, Kaplan JO, Levis S, Lucht W, Sykes MT, Thonicke K, Venesvsky S. 2003. Evaluation of ecosystem dynamics, plant geography and terrestrial carbon cycling in the LPJ dynamic global vegetation model. Glob Change Biol 9:161-85.

Smith AJE. 1978. The moss flora of Britain and Ireland. 1st edn Cambridge: Cambridge University Press.

Sokal RR, Rohlff FJ. 1995. Biometry. 3rd edn. New York: Freeman.

Turetsky MR. 2003. Bryophytes in carbon and nitrogen cycling. Bryologist 106:395-409.

Turetsky MR, Crow SE, Evans RJ, Vitt DH, Wieder RK. 2008. Trade-offs in resource allocation among moss species control decomposition in boreal peatlands. J Ecol 96:1297-305.

Van Breemen N. 1995. How Sphagnum bogs down other plants. Trends Ecol Evol 10:270-5.

Van der Meijden R. 1990. Heukels Flora van Nederland. 21st edn. Groningen: Wolters-Noordhoff.

Vasander H, Kettunen A. 2006. Carbon in boreal peatlands. In Wieder RK, Vitt DH, Eds. Boreal peatland ecosystems, Ecological studies, Vol. 188. Springer Verlag: Heidelberg. p 165-94.

Verhoeven JTA, Toth E. 1995. Decomposition of Carex and Sphagnum litter in fens: effect of litter quality and inhibition by living tissue homogenates. Soil Biol Biochem 27:271-5.

Verhoeven JTA, Maltby E, Schmitz MB. 1990. Nitrogen and phosphorus mineralization in fens and bogs. J Ecol 78:713-26.

Vitt DH, Wieder RK, Scott KD, Faller S. 2009. Decomposition and peat accumulation in rich fens of boreal Alberta, Canada. Ecosystems 12:360-73.

Wardle DA, Bonner KI, Nicholson KS. 1997. Biodiversity and plant litter: experimental evidence which does not support the view that enhanced species richness improves ecosystem function. Oikos 79:247-58.

Wardle DA, Nilsson M-C, Zackrisson O, Gallet C. 2003. Determinants of litter mixing effects in a Swedish boreal forest. Soil Biol Biochem 35:827-35. 